\title{
Apoptotic Effects on HL60 Human Leukaemia Cells Induced by Lavandin Essential Oil Treatment
}

\author{
Valentina Laghezza Masci ${ }^{1,+}{ }^{+}$, Elisa Ovidi ${ }^{1,+}{ }^{-}$, Anna Rita Taddei ${ }^{2}$, Giovanni Turchetti ${ }^{1}(\mathbb{D}$, \\ Antonio Tiezzi ${ }^{1}$, Pierluigi Giacomello ${ }^{3} \mathbb{D}$ and Stefania Garzoli ${ }^{3, * \mathbb{D}}$ \\ 1 Department for the Innovation in Biological, Agrofood and Forestal Systems, Tuscia University, \\ 01100 Viterbo, Italy; laghezzamasci@unitus.it (V.L.M.); eovidi@unitus.it (E.O.); g.turchetti@unitus.it (G.T.); \\ antoniot@unitus.it (A.T.) \\ 2 High Equipment Centre, Tuscia University, 01100 Viterbo, Italy; artaddei@unitus.it \\ 3 Department of Drug Chemistry and Technology, Sapienza University, 00185 Rome, Italy; \\ pierluigi.giacomello@uniroma1.it \\ * Correspondence: stefania.garzoli@uniroma1.it; Tel.: +06-499-13611; Fax: +06-499-13602 \\ + These authors contributed equally to the manuscript.
}

Academic Editor: Luca Forti

Received: 24 December 2019; Accepted: 23 January 2020; Published: 26 January 2020

\begin{abstract}
Recent scientific investigations have reported a number of essential oils to interfere with intracellular signalling pathways and to induce apoptosis in different cancer cell types. In this paper, Lavandin Essential Oil (LEO), a natural sterile hybrid obtained by cross-breeding L. angustifolia $\times$ L. latifolia, was tested on human leukaemia cells (HL60). Based on the MTT results, the reduced cell viability of HL60 cells was further investigated to determine whether cell death was related to the apoptotic process. HL60 cells treated for $24 \mathrm{~h}$ with LEO were processed by flow cytometry, and the presence of Annexin V was measured. The activation of caspases-3 was evaluated by western blot and immunofluorescence techniques. Treated cells were also examined by scanning and transmission electron microscopy to establish the possible occurrence of morphological alterations during the apoptotic process. LEO main compounds, such as linalool, linalyl acetate, 1,8-cineole, and terpinen-4-ol, were also investigated by MTT and flow cytometry analysis. The set of obtained results showed that LEO treatments induced apoptosis in a dose-dependent, but not time-dependent, manner on HL60 cells, while among LEO main compounds, both terpinen-4-ol and linalyl acetate were able to induce apoptosis.
\end{abstract}

Keywords: Lavandin Essential Oil; HL60; MTT test; flow cytometry; apoptosis; caspase-3; electron microscopy; immunofluorescence techniques

\section{Introduction}

It has been well established that natural compounds are a source of new molecules of potential pharmaceutical interest [1]. The chemical characteristics and biological activities of natural products, especially Essential Oils (EOs), are object of great interest thanks to their various wide applications, mainly in the medical, pharmaceutical, and cosmetic fields [2].

Plants containing EOs are only a small percentage of the wider plant molecule population; these species are defined as aromatic plants and are distributed all over the world [3]. The genera to which they belong are limited to a small number of families, such as Asteraceae, Cupressaceae, Lamiaceae, Lauraceae, Myrtaceae, Poaceae, Piperaceae, and Rutaceae [4].

The main constituents of EOs are monoterpene hydrocarbons, sesquiterpene hydrocarbons, oxygenated sesquiterpenes, oxygenated monoterepenes, and esters [5]. 
The numerous medicinal benefits of EOs have been widely demonstrated. They have therapeutic effects and pharmaceutical uses in cardiovascular disease, cancer, and diabetes, alongside applications in skin penetration enhancement, antimicrobial, massage therapy, neuroprotection, and aromatherapy, as well as anti-aging properties [6]. In particular, it was reported that the EOs extracted from Lavandula possess different properties, including antibacterial activities against many types of bacteria, such as foodborne pathogens, human pathogenic bacteria, and environmental bacteria [7-12].

Current studies show how EOs can affect intracellular signalling pathways, inducing apoptosis or autophagy in different cancer cells models, thus representing excellent candidates for the treatment and prevention of cancer development $[13,14]$.

Apoptosis, a type of programmed cell death characterized by several morphological and biochemical features, such as plasma membrane blebbing, cell shrinkage, chromatin condensation, DNA fragmentation, and the formation of apoptotic bodies [15], plays an important role during the normal development of tissues and in cellular homeostasis by allowing the elimination of damaged cells. A deregulation of apoptosis is associated with a variety of diseases, such as cancer.

Three different extracts and the essential oil of L. angustifolia have been reported to possess cytotoxic and proapoptotic activities on two human cancer cell lines, Hela and MCF-7 cells [16]. Sobral et al. [17], in a review, documented that the monoterpenes found in EOs possess antitumor activities, as also reported in other papers [6,14], and their roles in the apoptotic process have been highlighted. Woronuk and coworkers [18] reported that several volatile components of lavander EOs have therapeutic effects; in particular, linalool and 1,8-cineole induced apoptosis of cancer cells.

As reported in our previous work [19], Lavandin Essential Oil (LEO) mainly consists of four compounds belonging to the monoterpene family: terpinen-4-ol, linalyl acetate, linalool, and 1,8-cineole, which have been previously examined for their antitumor activity [20-23].

The aim of this study was to evaluate the possible apoptotic activity induced by pure LEO and its most abundant components on HL60 cells. Techniques and assays such as MTT, flow cytometry, Western blot, immunofluorescence, and scanning (SEM) and transmission (TEM) electron microscopy were used.

\section{Results}

\subsection{Cytotoxicity Assay (MTT)}

An MTT assay was performed to evaluate the cell cytotoxicity induced by LEO and treatment with LEO's main compounds (linalool, linalyl acetate, 1,8-cineole, and terpinen-4-ol). Table 1 reports the $\mathrm{EC}_{50}$ values of the LEO treatments. The data are shown as the mean \pm standard deviation (SD) of three individual experiments. After $24 \mathrm{~h}$ of LEO treatment, the $\mathrm{EC}_{50}$ was $117.66 \pm 5.50 \mu \mathrm{g} / \mathrm{mL}$. No meaningful variation concerning $\mathrm{EC}_{50}$ values after 48 and $72 \mathrm{~h}(116.33 \pm 19.50 \mu \mathrm{g} / \mathrm{mL}$ and $110.00 \pm 1.73$ $\mu \mathrm{g} / \mathrm{mL}$, respectively) occurred. The $\mathrm{EC}_{50}$ for the positive puromycin control was $0.57 \pm 0.05 \mu \mathrm{g} / \mathrm{mL}$.

Table 1. $\mathrm{EC}_{50}$ obtained by a dose-dependent MTT assay after 24,48 , and $72 \mathrm{~h}$ of Lavandin Essential Oil (LEO) treatments and after $24 \mathrm{~h}$ of main compound treatments on HL60 cells. The values are expressed as the mean $\pm \mathrm{SD}$.

\begin{tabular}{cc}
\hline Samples & EC $_{\mathbf{5 0}} \pm \mathbf{S D}$ \\
\hline LEO 24 h & $117.66 \pm 5.50 \mu \mathrm{g} / \mathrm{mL}$ \\
LEO 48 $\mathrm{h}$ & $116.33 \pm 19.50 \mu \mathrm{g} / \mathrm{mL}$ \\
LEO 72 $\mathrm{h}$ & $111.00 \pm 1.73 \mu \mathrm{g} / \mathrm{mL}$ \\
puromycin & $0.57 \pm 0.05 \mu \mathrm{g} / \mathrm{mL}$ \\
terpinen-4-ol & $6.30 \pm 0.7 \mu \mathrm{g} / \mathrm{mL}$ \\
linalyl acetate & $4.93 \pm 0.22 \mu \mathrm{g} / \mathrm{mL}$ \\
linalool & $>30 \mu \mathrm{g} / \mathrm{mL}$ \\
1,8-cineole & $>30 \mu \mathrm{g} / \mathrm{mL}$ \\
\hline
\end{tabular}




\subsection{Flow Cytometry and Apoptotic Staining}

Based on the results obtained by the MTT assays, the reduced cell viability of HL60 was further investigated to assess cell death and detect if it was related to the apoptotic process. HL60 samples treated for $24 \mathrm{~h}$ with LEO were processed for flow cytometry, and the presence of Annexin V-FITC/PI was investigated (Figure 1a-b). As shown in Figure 1a, HL60 cells treated with solvent (DMSO) for 24 $\mathrm{h}$ showed a low percentage apoptosis rate $(9.26 \% \pm 1.23 \%)$ corresponding to the sum of the percentage of Annexin V-positive/PI-negative staining and double-positive staining cells (early and late apoptosis, respectively); the same result was obtained in the control experiments with the cells grown in the culture medium (data not shown). For LEO treatments, the apoptotic rate was $70.22 \% \pm 6.93 \%$ after $24 \mathrm{~h}$, showing a high level of Annexin V-positive/PI-negative staining and double-positive staining (Figure 1b).
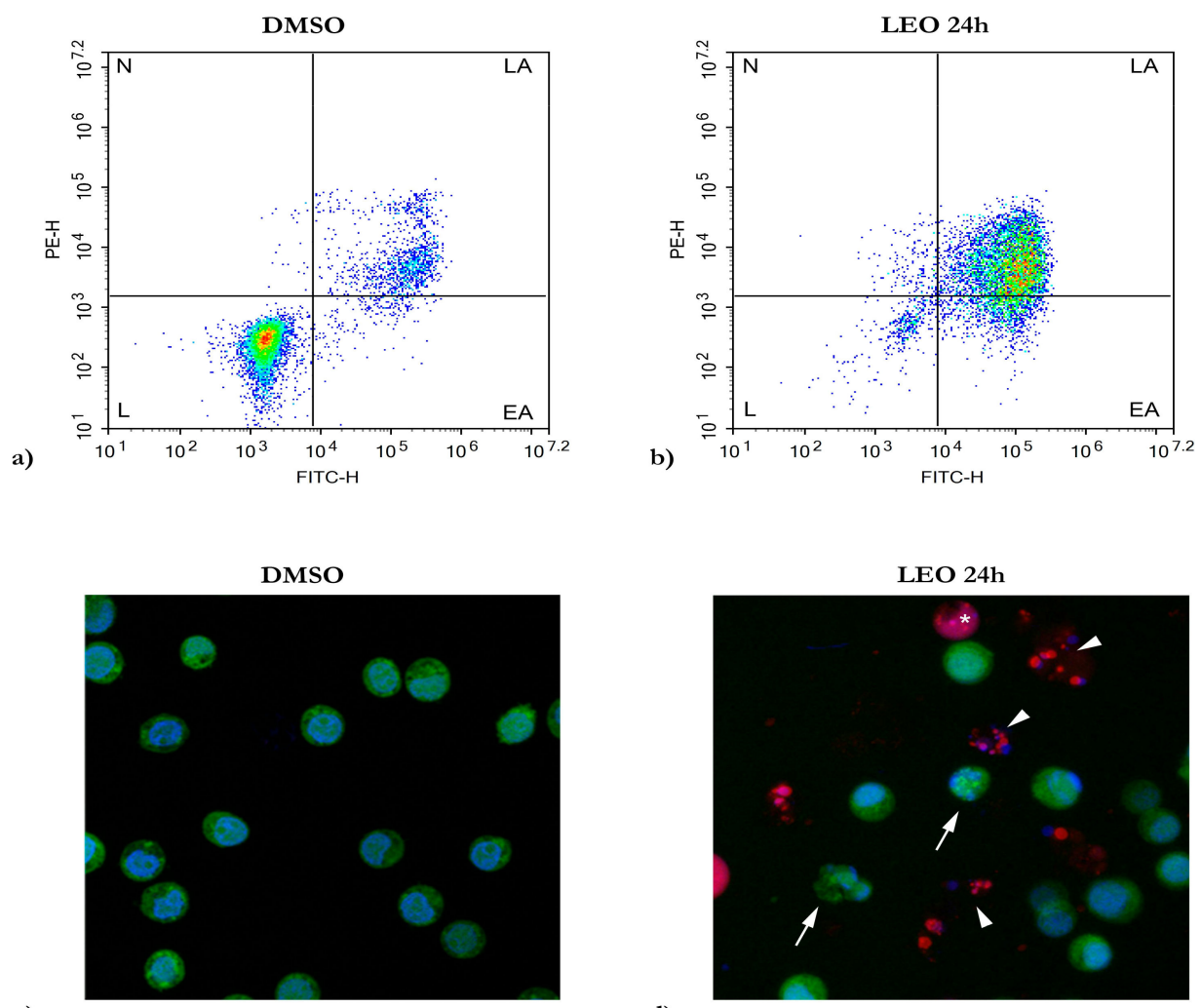

c)

d)

Figure 1. Evaluation of apoptosis induced by LEO treatments. Flow cytometry analysis for Annexin V-FITC/PI staining. (a) DMSO treated HL60 cells, solvent control; (b) HL60 treated with LEO for 24 h; (L) live cells, (EA) early apoptotic cells, (LA) late apoptotic cells, (N) necrotic cells. (c,d) Apoptosis assay using fluorescein diacetate (FDA), propidium iodide (PI), and Hoechst 33342, in a confocal microscopy analysis in samples treated with DMSO for $24 \mathrm{~h}$ (c) and with LEO for $24 \mathrm{~h}$ (d). EA (arrows), LA (arrows heads), N (asterisk).

To confirm the flow cytometry results, an apoptosis assay using fluorescein diacetate (FDA), propidium iodide (PI) and Hoechst 33,342 was carried out by confocal microscopy analysis. In Figure 1c, DMSO treated samples revealed the presence of double stained living cells possessing blue nuclei, with the regular contour stained by Hoechst 33,342 and the vital cytoplasm with a green fluorescence staining through the FDA, a cell-permeate esterase substrate used as a viability probe. After $24 \mathrm{~h}$, in the LEO treated samples, some cells appeared vital (Figure 1d), showing the same staining patterns observed in the DMSO treated sample. Numerous cells were identified in several stages of apoptosis, showing cell shrinkage, chromatin condensation, cell membrane blebbing, and apoptotic bodies (Figure 1d). Some 
cells appeared in the early stages of apoptosis with blue condensed or fragmented nuclei and green fluorescent cytoplasm with membrane blebbing (arrows). In other cells, the presence of nuclei with red/pink fluorescence or apoptotic bodies demonstrated a late apoptosis stage, confirming the flow cytometry results (arrows heads). Few necrotic cells were detected (asterisk).

\subsection{Scanning and Transmission Electron Microscopy}

The use of electron microscopy technique is considered the "gold standard" method for the identification of apoptotic cells [24]. The ultrastructural changes that occurred during the apoptotic process after LEO treatment were investigated. TEM (Figure 2a) and SEM (Figure 2b) micrographs of the DMSO treated samples showed the regular ultrastructure of the HL60 cells, with a roundish cellular shape and a plasma membrane rich in protrusions (such as microvilli). In the LEO and puromycin treated samples, electron microscopy images defined a typical apoptotic process, with changes in cellular morphology. Low magnification TEM images of LEO (Figure 2c) and puromycin treatments (Figure 2f) revealed the presence of cells in different apoptotic stages. Nuclear $(\mathrm{N})$ and cytoplasm condensation (C) was present and clearly visible for the LEO and puromycin treatments (Figure 2d,g, respectively). The Karyorrhexis process was confirmed by the presence of half-moon (arrows) and crescent shape nuclei. Membrane-bound apoptotic bodies (AB) were present in both of the treatments. SEM images showed the loss of the roundish shape of apoptotic cells with a reduction of the protrusions and plasma membrane blebbing (arrows heads) in the LEO (Figure 2e) and puromycin treated cells (Figure 2h).

\subsection{Cleaved Caspase-3 Expression Investigated by Western Blotting and Immunofluorescence Analysis}

To define the HL60 apoptotic process, we investigated cleaved caspase-3 expression. Data indicated that after $24 \mathrm{~h}$ of LEO treatment, the cleaved caspase- 3 monoclonal antibody recognized two bands $(17 \mathrm{kDa}$ and $19 \mathrm{kDa})$, which correspond to the large and small fragments of activated caspase-3 resulting from the cleavage adjacent to Asp175 in the caspase-3 aminoacidic sequence. $\beta$-actin expression served as an internal control, while the puromycin was used as a positive control to confirm the activation of caspase-3 (Figure 3a).

Confocal microscopy immunofluorescence analysis confirmed cleaved-caspase- 3 expression in accordance with the Western blotting analysis (Figure 3b-d). In DMSO treated cells, the nuclei appeared to have normal morphology, and cleaved caspase-3 was not detected under blue staining. After $24 \mathrm{~h}$ of LEO and puromycin treatments, anti-cleaved caspase 3-antibody labeled the cytoplasms of numerous cells, thereby confirming apoptotic process activation.

\subsection{MTT and Flow Cytometry Analysis of LEO Main Compounds}

In our previous work [19], we investigated the chemical composition of LEO by GC/MS and highlighted that terpinen-4-ol, linalyl acetate, linalool, and 1,8-cineole are main LEO compounds. In this work, we investigated which of these compounds were capable of inducing an apoptotic effect. Therefore, MTT assays were carried out using terpinen-4-ol, linalyl acetate, linalool, and 1,8-cineole; Table 1 reports the obtained $\mathrm{EC}_{50}$ values. Main cytotoxic compounds that resulted were terpinen-4-ol and linalyl acetate with an $\mathrm{EC}_{50}$ of $6.30 \pm 0.7 \mu \mathrm{g} / \mathrm{mL}$ and $4.93 \pm 0.22 \mu \mathrm{g} / \mathrm{mL}$, respectively. Linalool and 1,8-cineole were revealed to be less cytotoxic on HL60 cells, thus demonstrating the mortality of half-cell populations with higher doses ( $>30 \mu \mathrm{g} / \mathrm{mL}$ for both of the compounds).

For LEO treatments, the reduced cell viability of HL60 was further investigated with flow cytometry. The presence of Annexin V-FITC/PI staining was carried out to test the potential role of the main LEO compounds in the apoptotic process (Figure 4). 


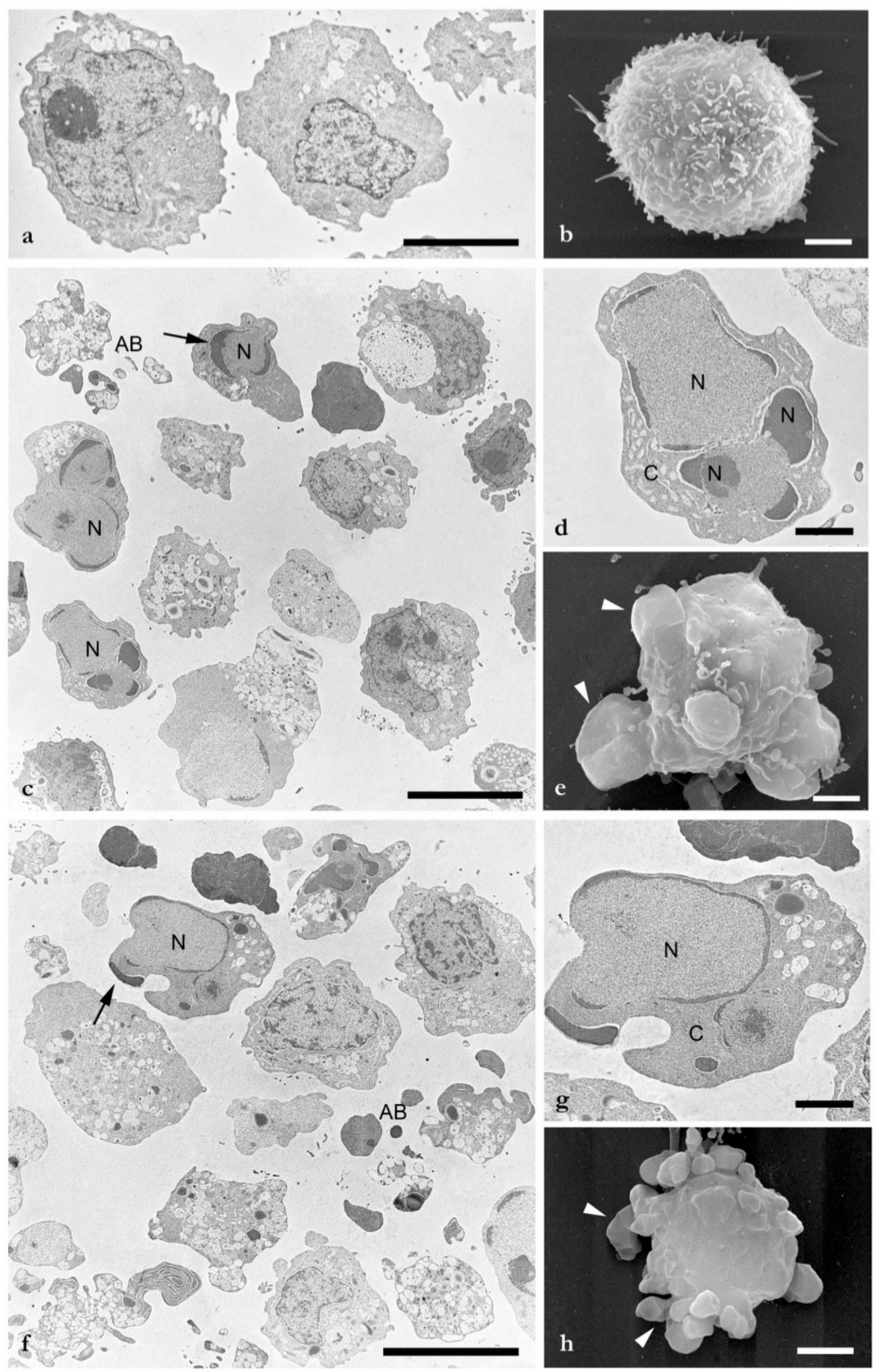

Figure 2. SEM and TEM investigations of HL60 cells were carried out to evaluate the apoptosis morphological changes induced by LEO treatments for $24 \mathrm{~h}$; (a) TEM of DMSO treated HL60 cells, solvent control; (b) SEM of DMSO treated HL60 cells, solvent control; (c) TEM of HL60 treated with LEO; (d) higher TEM magnification of HL60 treated with LEO; (e) SEM of LEO treated HL60 cells; (f) TEM of puromycin treated HL60 cells; (g) higher TEM magnification of HL60 treated with puromycin; (h) SEM of puromycin-treated HL60 cells. Nuclei (N), cytoplasm (C), half-moon nuclei (arrows), membrane apoptotic bodies (AB), plasma membrane blebbing (arrows heads). Bars =a) $5 \mu \mathrm{m} ; \mathrm{b}, \mathrm{d}, \mathrm{e}, \mathrm{g}, \mathrm{h}$ ) $2 \mu \mathrm{m}$; , f) $10 \mu \mathrm{m}$.

In Figure 4a,b, HL60 cells treated with terpinen-4-ol and linalyl acetate for $24 \mathrm{~h}$ showed a high percentage apoptosis rate $(96.74 \% \pm 1.51 \%$ and $97.83 \% \pm 2.34 \%$, respectively) with a high level of Annexin V-positive/PI-negative staining and double-positive staining. For the linalool and 1,8-cineole treatments, the apoptotic rates were $44.8 \% \pm 6.31 \%$ and $29.72 \% \pm 5.72 \%$ (Figure $4 \mathrm{c}, \mathrm{d}$ ). 


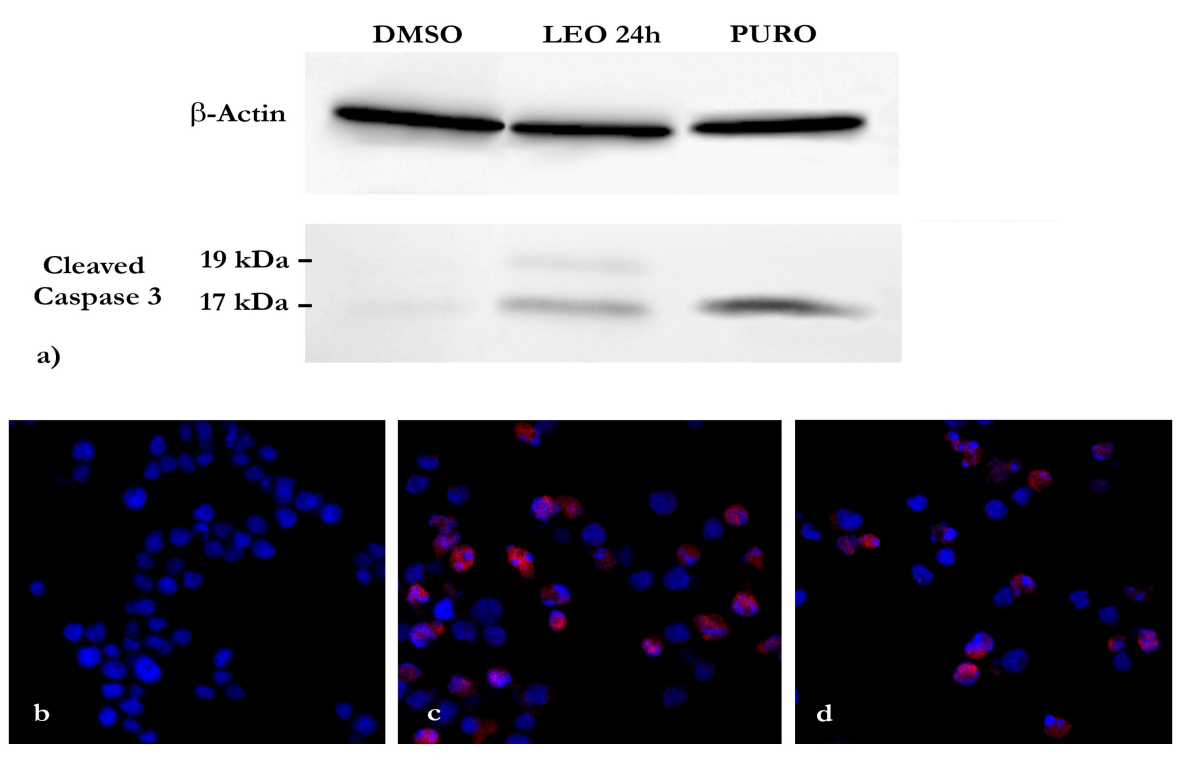

Figure 3. Cleaved caspase-3 expression investigated by Western blotting and immunofluorescence analysis using a cleaved caspase-3 monoclonal antibody. (a) Western blotting analysis. In the lower panel, cleaved capese-3 detection in DMSO, LEO, and puromycin treated HL60 cells; in the upper panel, $\beta$-actin detection as the internal control; (b) immunofluorescence analysis in the confocal microscopy of DMSO treated HL60 cells, (c) LEO treated HL60 cells, and (d) HL60 puromycin treated HL60 cells.
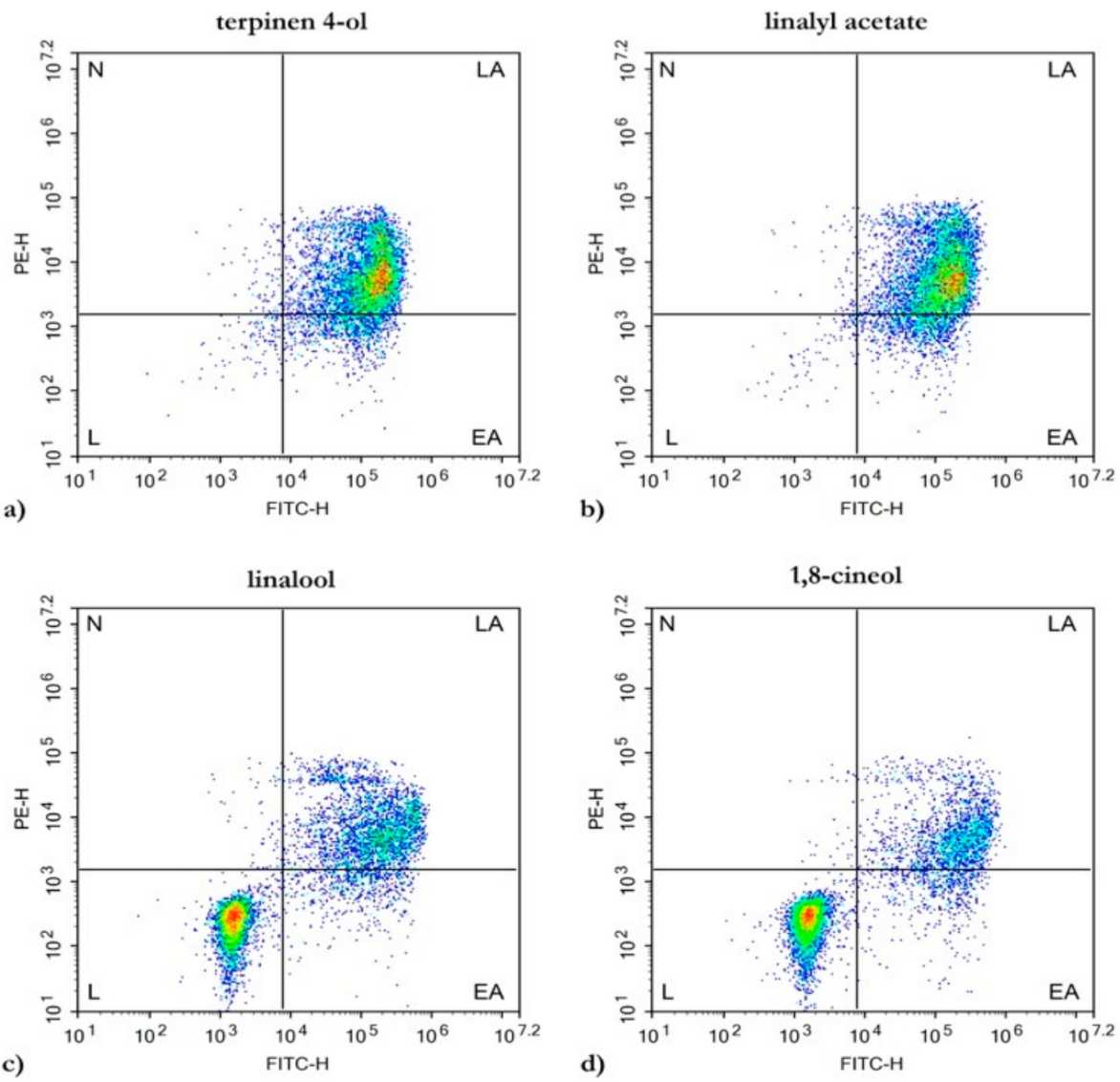

Figure 4. Evaluation of apoptosis in HL60 cells induced by treatment with the main LEO compounds. Flow cytometry analysis for Annexin V-FITC/PI staining. (a) terpinen-4-ol; (b) linalyl acetate; (c) linalool; (d) 1,8-cineole. (L) live cells, (EA) early apoptotic cells, (LA) late apoptotic cells, (N) necrotic cells. 


\section{Discussion}

It has been well established that numerous natural compounds have beneficial effects on human health, and, in some cases, they are also able to induce apoptosis in different cancer cells; such compounds have possible applications in cancer therapy. Among plant compounds, some EOs and their constituents show antimutagenic, antiproliferative, antioxidant, and detoxifying activities [13,25].

Blowman and coworkers [13] reviewed that EOs have anticancer properties that act through various mechanisms and induce both the intrinsic (or mitochondria dependent) and extrinsic (or death receptor-dependent) apoptosis pathways. Among the Lamiaceae family, the anticancer potential of the Origano onites EO has been studied in vitro and in vivo by testing its antiproliferative activity on CT26 and HT-29 colon cancer cells, and an apoptosis-related mechanism was detected in these studies [26].

As we already reported [19], LEO mainly consists of four compounds belonging to the monoterpene family: linalool (41.6\%) linalyl acetate (23.0\%), 1,8-cineole (5.2\%), and terpinen-4-ol (4.8\%). In this paper we aimed to extend knowledge on LEO's anticancer properties by carrying out investigations on HL60 human leukemia cells. The MTT results have shown that LEO treatment is dose- and not time-dependent since the $\mathrm{EC}_{50}$ values obtained at different times of incubation did not show significant differences, ranging from $117.66 \pm 5.50 \mu \mathrm{g} / \mathrm{mL}$ after $24 \mathrm{~h}$ to $111.00 \pm 1.73 \mu \mathrm{g} / \mathrm{mL}$ after $72 \mathrm{~h}$ of treatment.

Previous investigations on L. angustifolia EO have reported cytotoxic activity on different cancer cell lines, with $\mathrm{EC}_{50}$ values of $80.62 \pm 1.04 \mu \mathrm{g} / \mathrm{mL}$ on Hela cells and $88.90 \pm 1.71 \mu \mathrm{g} / \mathrm{mL}$ on A549, confirming the high cytotoxic properties of the EOs from the Lamiaceae family on cancer cells, as observed in our results [9]. Gezici [27] determined that the cell growth and cell viability in three different cancer cell lines (A549, H1299, and C6) were affected by lavender (L. angustifolia Mill.) EOs at a low concentration and with minimum exposure time.

Furthermore, the therapeutic effects of $L$ angustifolia EO were investigate on human prostate cancer cells, showing potent cytotoxicity against both DU145 and PC-3 cell lines, with an EC 50 0.199\% $\pm 0.026 \%$ and $0.037 \% \pm 0.011 \%(v / v)$, respectively [20].

In the present paper, the observed cell viability reduction is due to the activation of an apoptotic process as a consequence of LEO treatments.

Apoptosis is a programmed and tightly controlled type of cell death characterized by distinct morphological features, such as nuclear condensation, cell shrinkage, membrane blebbing, DNA fragmentation, and apoptotic bodies as a consequence of cell breakdown [28]. Apoptosis can be defined by measuring the presence of Annexin $\mathrm{V}$ binding to membrane bound phosphatidylserine, which is normally located in the inner plasma membrane of healthy cells and becomes externalized on the outer plasma membrane of cells exposed to pro-apoptotic stimuli. After LEO treatments, Annexin V-positive/PI-negative staining and double positive cell staining defined early and late apoptosis, respectively, with a total percentage of apoptotic cell population $70.22 \% \pm 6.93 \%$ after $24 \mathrm{~h}$. The flow cytometry results were confirmed by an apoptotic assay using fluorescein diacetate (FDA), propidium iodide (PI), and Hoechst 33,342 in a confocal microscopy analysis. LEO treated samples for 24 h showed similar staining to that obtained by puromycin, an apoptosis inducer of MCF-7 breast cancer cells [29]. In our investigations, numerous cells changed their normal morphologies after LEO treatments, showing, at the same time, chromatin condensation, cell membrane blebbing, and the formation of apoptotic bodies. FDA green fluorescent staining was observed in the vital cytoplasm and in early apoptotic cells in combination with Hoechst 33,342 stained nuclei, which appeared to be condensed or fragmented. In late apoptotic stages, no-green fluorescent staining was observed, and red/pink stained nuclei were evident, confirming the propidium iodide entrance via the non-functional cell membrane. Further, numerous apoptotic bodies were visible. Few necrotic cells were detected by red nuclei [30].

Tayarani-Najaran et al. [16] found higher antiproliferative and apoptosis induction activity in HeLa and MCF-7 cells by EtOH and n-hexane extracts of L. angustifolia than that inducted by its EO, for which the apoptotic rate was $27.4 \%$ with $400 \mu \mathrm{g} / \mathrm{mL}$ of treatment after $48 \mathrm{~h}$. In prostate cancer cells, treatment with $0.05 \%(\mathrm{v} / \mathrm{v})$ for $48 \mathrm{~h}$ determined an apoptotic rate (early and late) of $74.76 \%$ for PC3 cells and $10.64 \%$ for DU145 cells [20]. 
Electron microscopy investigations allowed us to define the morphological alterations after LEO treatments and clearly showed the occurrence of the apoptotic process. The morphological changes accompanying different apoptotic stages were evinced by cell shrinkage (nucleus and cytoplasm condensation), karyorrhexis (with the presence of half-moon and crescent shape nuclei), and the formation of apoptotic bodies, in full agreement with the previously reported data [24].

Most of the morphological modifications that occur in the apoptotic process are regulated by caspase family members, cysteine proteases consisting of "initiator" caspases and "executioner" caspases responsible for activating the proteins directly involved in programmed cell death [31]. Cleaved caspases-3, as an executioner caspase member, is a crucial mediator of apoptosis responsible for the proteolytic cleavage of many key proteins [15,32-34]. To further confirm the effect of LEO on apoptosis induction, cleaved caspase-3 expression was investigated and confirmed by Western blotting and an immunofluorescence analysis in HL-60 cells treated with LEO and puromycin for $24 \mathrm{~h}$.

The antiproliferative and apoptosis induction effects of LEO may be due to its composition $[14,18,35]$. EC 50 values obtained after $24 \mathrm{~h}$ of treatment with these compounds revealed that relevant activity was obtained by terpinen-4-ol $(6.30 \pm 0.7 \mu \mathrm{g} / \mathrm{mL})$ and by lynalyl acetate $(4.93 \pm$ $0.22 \mu \mathrm{g} / \mathrm{mL}$ ). Linalool and 1,8-cineole had an $\mathrm{EC}_{50}>30 \mu \mathrm{g} / \mathrm{mL}$

To define if the apoptotic effects observed in HL60 were related to LEO's main compounds, investigations were carried out via flow cytometry techniques. After $24 \mathrm{~h}$ of treatments, terpinen-4-ol and linalyl acetate showed high apoptotic rates $(96.74 \% \pm 1.51 \%$ and $97.83 \% \pm 2.34 \%$, respectively), while minor apoptotic induction effects were observed by linalool and 1,8 -cineole $(44.8 \% \pm 6.31 \%$ and $29.72 \% \pm 5.72 \%$, respectively).

Terpinen-4-ol exhibited cytotoxicity in human leukemic HL-60 cells, with an $\mathrm{EC}_{50}$ of $30 \mu \mathrm{M}$, by both autophagy and apoptosis processes, whereas no activity was found in U937 cells [21]. As described by Wu and collaborators, terpinen-4-ol treatment induced apoptosis in NSCLC cells in a dose-dependent manner and by a mitochondria-mediated pathway [36].

In HCT-116, a combination of linalyl acetate, terpineol, and camphor determined the induction of the apoptotic process with greater efficacy than observed in normal human intestinal cells [37]. Zhao et al. reported that the apoptotic rates induced by linalool and linalyl acetate treatments $(2.5 \mu \mathrm{M})$ for $24 \mathrm{~h}$ on PC-3 cells, were $67.11 \%$, and $56.14 \%$, respectively, whereas on DU145 cells, the apoptotic cell populations were $21.47 \%$, and $12.15 \%$, respectively [20]. Numerous papers reported that the linalool has a pivotal role in the induction and activation of apoptosis in different cancer cell lines $[20,22,38,39]$.

Likewise, 1,8-cineole treatment on Molt 4B and HL60 cells induced DNA fragmentation and specific inductions of apoptosis in a dose-dependent (from 5 to $10 \mu \mathrm{M}$ ) and time-dependent (from $12 \mathrm{~h}$ to $48 \mathrm{~h}$ ) manner [23]. In RKO cells, a $-50 \mathrm{mM}$ treatment of 1,8-cineole for $24 \mathrm{~h}$ determined the apoptotic induction [40]. Moreover, an intrinsic apoptosis activation induced by 1,8-cineole (0.2 and 0.4 $\mu \mathrm{L} / \mathrm{mL}$ ) in $\mathrm{KB}$ cells was reported, with apoptotic rates of $17.3 \% \pm 2.12 \%$ and $34.2 \% \pm 1.34 \%$, respectively induced via mitochondrial- and caspase-dependent mechanisms [41].

\section{Materials and Methods}

\subsection{Materials}

The LEO used in the present experiments (IT BIO 007 D86K, lot number MGL01/18) was a kind gift of Azienda Agricola Podere dell'Arco (Viterbo, Lazio, Italy) as a steam distilled sample obtained from a cultivar of lavandin (Lavandula $x$ intermedia "Grosso"). Linalyl acetate (CAS 115-95-7), terpinen-4-ol (CAS 562-74-3), linalool (CAS 78-70-6), and 1,8-cineole (CAS 470-82-6) were purchased from Merck KGaA (Darmstadt, Germany).

\subsection{Cell Growth and Maintenance}

Human promyelocytic leukemia cells HL60, obtained from ATCC ${ }^{\circledR}$ (American Type Culture Collection, Manassas, VA, US), were maintained in an RPMI-1640 medium supplemented with 10\% 
foetal bovine serum, $2 \mathrm{mM}$ L-glutamine, $50 \mathrm{U} / \mathrm{mL}$ penicillin, and $50 \mu \mathrm{g} / \mathrm{mL}$ streptomycin and incubated at $37^{\circ} \mathrm{C}$ in a humidified atmosphere with $5 \% \mathrm{CO}_{2}$.

\subsection{MTT Assay}

The cytotoxicity effects of LEO and pure compounds were investigated by an MTT-assay [42]. $2 \times 10^{4}$ cells/well in complete RPMI medium were seeded in a 96-well micro plate. LEO was previously dissolved at a concentration of $1 \mathrm{~g} / \mathrm{mL}(w / v)$ in dimethyl sulfoxide (DMSO), and ten different concentrations (from $1 \mathrm{mg} / \mathrm{mL}$ to $0.0019 \mathrm{mg} / \mathrm{mL}$, done twice to ten dilutions) were used for calculating the $\mathrm{EC}_{50}$ value. Pure compounds were dissolved in $\mathrm{DMSO}$, and ten different concentrations were used (twice to ten dilutions, from 15.4 were used for calculatinterpinen 4-ol, linalool, and 1,8 cineol, and from 19.66 cineol, and from 19.6 linalyl acetate). Puromycin was used as a positive control (from $25 \mu \mathrm{g} / \mathrm{mL}$ to $0.045 \mu \mathrm{g} / \mathrm{mL}$, twice to ten dilutions), and DMSO at $0.01 \%$ was used as a solvent control. After 24, 48, and $72 \mathrm{~h}$ for pure compounds, the medium containing the treatments was removed, and $100 \mu \mathrm{L}$ of MTT solution $(0.5 \mathrm{mg} / \mathrm{mL})$ was added to each well and incubated in the dark at $37^{\circ} \mathrm{C}$ for $3 \mathrm{~h}$. The formazan crystals were dissolved in $100 \mu \mathrm{l}$ of DMSO, and the absorbance was measured at $570 \mathrm{~nm}$. The concentration at which a substance exerts half of its maximal response values $\left(\mathrm{EC}_{50}\right)$ was calculated by using AAT Bioquest, Inc. (Quest Graph ${ }^{\mathrm{TM}}$ EC50 Calculator, Retrieved from https://www.aatbio.com/tools/ec50-calculator; 5 November 2019).

\subsection{Flow Cytometry}

Apoptosis detection was performed by using an Annexin V-FITC and PI apoptosis kit (eBioscience $^{\mathrm{TM}}$, San Diego, CA, US). HL60 cells were plated at a $3 \times 10^{5}$ cells $/ \mathrm{mL}$ density onto a six well plate. After $24 \mathrm{~h}$ of incubation, the cells were treated with LEO at $0.2 \mathrm{mg} / \mathrm{mL}$ and with pure compounds at $77.1 \mu \mathrm{g} / \mathrm{mL}$ for terpinen-4-ol, linalool, and 1,8-cienole, and at $98.1 \mu \mathrm{g} / \mathrm{mL}$ for linalyl acetate. Cells grown in media containing an equivalent amount of DMSO served as the solvent control. After $24 \mathrm{~h}$, the cells were stained with an Annexin V-FITC conjugate and propidium iodide, and the percentage of apoptotic, necrotic, and living cells was determined according to the protocol provided by the Annexin V-FITC and PI apoptosis kit. The cells' emitted fluorescence was analyzed by flow cytometry (NovoCyte, ACEA Biosciences Inc, San Diego, CA, US) through the NovoExpress 1.3.0 software (ACEA Biosciences Inc, San Diego, CA, US), acquiring $1 \times 10^{4}$ events per sample using the population plot "dot plot", where each point corresponds to a single event with a specific fluorescence signal in reference to the axes; Annexin V-FITC green fluorescence in abscissa vs. PE red fluorescence in ordinate. The experiments were repeated three times.

\subsection{Apoptosis Assay}

After LEO treatments, HL60 cells were stained to detect apoptosis and necrosis. After treatments with $\mathrm{LEO}$ and puromycin at $\mathrm{EC}_{50}$ concentrations for $24 \mathrm{~h}$, the samples were centrifuged at $2000 \mathrm{rpm}$ to collect cells and apoptotic bodies, and staining was performed with Propidium iodide $(20 \mu \mathrm{g} / \mathrm{mL})$, Fluorescein diacetate $(30 \mu \mathrm{g} / \mathrm{mL})$, and Hoechst 33,342 $(20 \mu \mathrm{g} / \mathrm{mL})$ in an RPMI medium at $37^{\circ} \mathrm{C}$ for $5 \mathrm{~m}$. After incubation, samples were mounted on slides and observed by a Zeiss LSM 710 Confocal Microscope (Carl Zeiss, Oberkochen, Germany) to capture images.

\subsection{Scanning and Transmission Electron Microscopy}

For the scanning and transmission electron microscopy analysis, HL60 cells were seeded at a $3 \times 10^{5}$ cells $/ \mathrm{mL}$ density onto a six well plate and incubated for $24 \mathrm{~h}$ in appropriate culture conditions.

After treatments with LEO and puromycin at $\mathrm{EC}_{50}$ concentrations for $24 \mathrm{~h}$, the cells were collected in tubes, washed with PBS, and fixed with $4 \%$ paraformaldehyde and $5 \%$ glutaraldehyde, $\mathrm{pH} 7.2$, in a $0.1 \mathrm{M}$ cacodylate buffer for $1 \mathrm{~h}$ at $4{ }^{\circ} \mathrm{C}$ [43]. After rinsing overnight in the same buffer, samples were post-fixed in $1 \%$ osmium tetroxide in a cacodylate buffer for $1 \mathrm{~h}$ at $4{ }^{\circ} \mathrm{C}$. After two washings in the same buffer, samples were dehydrated in a graded ethanol series. 
For Scanning Electron Microscopy (SEM), cells were dried by the critical point method using $\mathrm{CO}_{2}$ in a Balzers Union CPD 020, sputter-coated with gold in a Balzers MED 010 unit and observed by a JEOL JSM 5200 electron microscope (Jeol Ltd., Tokyo, Japan).

For Transmission Electron Microscopy (TEM), samples were fixed and dehydrated as described above and embedded in an Epon mixture resin. Thin sections $(50-70 \mathrm{~nm})$ were cut with Reichert Ultracut (Leica Microsystems, Wetzlar, Germay) and LKB Nova ultramicrotomes (LKB Vertriebs GmbH, Vienna, Austria) using a diamond knife, collected on copper grids, stained with uranyl acetate and lead citrate, and observed by a JEOL 1200EX II electron microscope.

\subsection{Western Blot}

HL60 cells were seeded at a $1 \times 10^{6}$ cells/mL density onto a petri dish and incubated for $24 \mathrm{~h}$. After treatments with LEO and puromycin at $\mathrm{EC}_{50}$ concentrations, the cells were lysed with a RIPA buffer on ice for $30 \mathrm{~m}$. Protein concentrations were determined by the Bradford test [44]. Samples were run on $10 \%$ SDS-PAGE and then electrotransferred onto a pure nitrocellulose membrane $(0.45 \mu \mathrm{m})$. The membrane was blocked with $5 \%$ bovine serum albumin and immunoblotted with cleaved caspase- 3 rabbit $\mathrm{mAb}$ and $\beta$-actin mouse $\mathrm{mAb}$ (Cell Signaling Technology, Leiden, The Netherlands). Anti-rabbit IgG and anti-mouse IgG HRP conjugate antibodies (Promega, Madison, WI, US) were used to detect the corresponding bands by acquiring images via a ChemiDoc XRS+ System (Bio Rad, Hercules, CA, Italy).

\subsection{Immunofluorescence Technique Observations}

Immunofluorescence observations were performed to investigate cleaved caspase- 3 expression in the LEO treated cell. After treatments with LEO and puromycin at $\mathrm{EC}_{50}$ concentrations for $24 \mathrm{~h}$, cells were processed, as reported in the literature [45], and subsequently incubated with a cleaved caspase-3 rabbit mAb (Cell Signaling Technology, Leiden, The Netherlands) diluted to 1:400 in a blocking buffer (5\% BSA in PBS) for $1 \mathrm{~h}$ at room temperature. After rinsing three times in PBS, the coverslips were dried and incubated with an Alexa Fluor ${ }^{\circledR} 488$ Goat Anti-Mouse IgG Antibody (Molecular Probes, Eugene, OR, USA) diluted to 1:100 in a blocking buffer. For evaluation of possible unspecific staining, control samples were prepared by omitting the primary antibody. After three washings in PBS, nucleic acid staining was obtained by incubation with Fluoroshield with 4',6-diamidino-2-phenylindole dihydrochloride (DAPI) (Merck KGaA, Darmstadt, Germany), and then samples were placed. The images were captured by a Zeiss LSM 710 Confocal Microscope (Carl Zeiss, Oberkochen, Germany.

\section{Conclusions}

In the present paper, a multidisciplinary research approach was performed to study the effects of LEO on HL60 human leukemia cells. Taken together, the obtained results clearly show that LEO treatments induced apoptosis in a dose- and not time-dependent manner, and, among the main LEO compounds, both terpinen-4-ol and linalyl acetate were able to induce apoptosis. Our findings open interesting possibilities for further deeper investigations into such compounds. In our laboratory, experimental work is being done on other human cancer cell lines.

Author Contributions: Conceptualization, V.L.M., E.O., and S.G.; methodology, V.L.M., S.G., and E.O.; investigation E.O., V.L.M., A.R.T., and G.T.; data curation, V.L.M. and E.O.; writing-original draft preparation, S.G.; writing—review and editing S.G., E.O., V.L.M., and S.G.; supervision, A.T. and P.G.; funding, A.T. and P.G. All authors have read and agreed to the published version of the manuscript.

Funding: This research received no external funding.

Acknowledgments: The authors are thankful to Azienda Podere dell'Arco, Viterbo, Italy, for providing lavandin essential oil (Lavandula $x$ intermedia).

Conflicts of Interest: The authors declare no conflict of interest. 


\section{References}

1. Bernardini, S.; Tiezzi, A.; Laghezza Masci, V.; Ovidi, E. Natural products for human health: An historical overview of the drug discovery approaches. Nat. Prod. Res. 2017, 6419, 1-25. [CrossRef]

2. El Asbahani, A.; Miladi, K.; Badri, W.; Sala, M.; Addi, E.H.A.; Casabianca, H.; El Mousadik, A.; Hartmann, D.; Jilale, A.; Renaud, F.N.R.; et al. Essential oils: From extraction to encapsulation. Int. J. Pharm. 2015, 483, 220-243. [CrossRef]

3. Svoboda, K.P.; Greenaway, R.I. Lemon scented plants. Int. J. Aromather. 2003, 13, 23-32. [CrossRef]

4. Kennedy, J.; Thorley, M. Pharmacognosy, Phytochemistry, Medicinal Plants (2nd ed.). Carbohydr. Polym. 2000, 42, 428-429. [CrossRef]

5. Tongnuanchan, P.; Benjakul, S. Essential Oils: Extraction, Bioactivities, and Their Uses for Food Preservation. J. Food Sci. 2014, 79. [CrossRef]

6. Edris, A.E. Pharmaceutical and therapeutic Potentials of essential oils and their individual volatile constituents: A review. Phyther. Res. 2007, 21, 308-323. [CrossRef] [PubMed]

7. Lis-Balchin, M.; Hart, S. Studies on the mode of action of the essential oil of LavenderLavandula angustifolia P. Miller). Phyther. Res. 1999, 13, 540-542. [CrossRef]

8. Martucci, J.F.; Gende, L.B.; Neira, L.M.; Ruseckaite, R.A. Oregano and lavender essential oils as antioxidant and antimicrobial additives of biogenic gelatin films. Ind. Crops Prod. 2015, 71, 205-213. [CrossRef]

9. Nikolić, M.; Jovanović, K.K.; Marković, T.; Marković, D.; Gligorijević, N.; Radulović, S.; Soković, M. Chemical composition, antimicrobial, and cytotoxic properties of five Lamiaceae essential oils. Ind. Crops Prod. 2014, 61, 225-232. [CrossRef]

10. Rota, C.; Carramiñana, J.J.; Burillo, J.; Herrera, A. In vitro antimicrobial activity of essential oils from aromatic plants against selected foodborne pathogens. J. Food Prot. 2004, 67, 1252-1256. [CrossRef]

11. Smigielski, K.; Prusinowska, R.; Stobiecka, A.; Kunicka-Styczyñska, A.; Gruska, R. Biological Properties and Chemical Composition of Essential Oils from Flowers and Aerial Parts of Lavender (Lavandula angustifolia). J. Essent. Oil-Bearing Plants 2018, 21, 1303-1314. [CrossRef]

12. Soković, M.; Marin, P.D.; Brkić, D.; van Griensven, L.J.L.D. Chemical Composition and Antibacterial Activity of Essential Oils of Ten Aromatic Plants against Human Pathogenic Bacteria Marina. Food 2008, 1, 220-226.

13. Blowman, K.; Magalhães, M.; Lemos, M.F.L.; Cabral, C.; Pires, I.M. Anticancer Properties of Essential Oils and Other Natural Products. Evidence-Based Complement. Altern. Med. 2018, 2018, 1-12. [CrossRef] [PubMed]

14. Fernandes, J. Antitumor Monoterpenes. In Bioactive Essential Oils and Cancer; de Sousa, D.P., Ed.; Springer: Cham, Switzerland, 2015; pp. 175-200, ISBN 9783319191447.

15. Elmore, S. Apoptosis: A review of programmed cell death. Toxicol. Pathol. 2007, 35, 495-516. [CrossRef] [PubMed]

16. Tayarani-Najaran, Z.; Amiri, A.; Karimi, G.; Emami, S.A.; Asili, J.; Mousavi, S.H. Comparative studies of cytotoxic and apoptotic properties of different extracts and the essential oil of lavandula angustifolia on malignant and normal cells. Nutr. Cancer 2014, 66, 424-434. [CrossRef] [PubMed]

17. Sobral, M.V.; Xavier, A.L.; Lima, T.C.; Sousa, D.P. De Review Article Antitumor Activity of Monoterpenes Found in Essential Oils. Hindawi Publ. Corp. e Sci. World J. 2014, 2014.

18. Woronuk, G.; Demissie, Z.; Rheault, M.; Mahmoud, S. Biosynthesis and Therapeutic Properties of Lavandula Essential Oil Constituents. Planta Med. 2011, 77, 7-15. [CrossRef]

19. Garzoli, S.; Turchetti, G.; Giacomello, P.; Tiezzi, A.; Masci, V.L.; Ovidi, E. Liquid and vapour phase of lavandin (Lavandula $\times$ intermedia) Essential Oil: Chemical composition and antimicrobial activity. Molecules 2019, 24, 2701. [CrossRef]

20. Zhao, Y.; Chen, R.; Wang, Y.; Qing, C.; Wang, W.; Yang, Y. In Vitro and in Vivo Efficacy Studies of Lavender angustifolia Essential Oil and Its Active Constituents on the Proliferation of Human Prostate Cancer. Integr. Cancer Ther. 2017, 16, 215-226. [CrossRef]

21. Banjerdpongchai, R.; Khaw-On, P. Terpinen-4-ol induces autophagic and apoptotic cell death in human leukemic HL-60 cells. Asian Pacific J. Cancer Prev. 2013, 14, 7537-7542. [CrossRef]

22. Gu, Y.; Ting, Z.; Qiu, X.; Zhang, X.; Gan, X.; Fang, Y.; Xu, X.; Xu, R. Linalool preferentially induces robust apoptosis of a variety of leukemia cells via upregulating p53 and cyclin-dependent kinase inhibitors. Toxicology 2010, 268, 19-24. [CrossRef] [PubMed] 
23. Moteki, H.; Hibasami, H.; Yamada, Y.; Katsuzaki, H.; Imai, K.; Komiya, T. Specific induction of apoptosis by 1,8-cineole in two human leukemia cell lines, butnot a in human stomach cancer cell line. Oncol. Rep. 2002, 9, 757-760. [PubMed]

24. Taatjes, D.J.; Sobel, B.E.; Budd, R.C. Morphological and cytochemical determination of cell death by apoptosis. Histochem. Cell Biol. 2008, 129, 33-43. [CrossRef]

25. von Schwarzenberg, K.; Vollmar, A.M. Targeting apoptosis pathways by natural compounds in cancer: Marine compounds as lead structures and chemical tools for cancer therapy. Cancer Lett. 2013, 332, 295-303. [CrossRef] [PubMed]

26. Spyridopoulou, K.; Fitsiou, E.; Bouloukosta, E.; Tiptiri-Kourpeti, A.; Vamvakias, M.; Oreopoulou, A.; Papavassilopoulou, E.; Pappa, A.; Chlichlia, K. Extraction, Chemical Composition, and Anticancer Potential of Origanum onites L. Essential Oil. Molecules 2019, 24, 2612. [CrossRef] [PubMed]

27. Gezici, S. Original article Promising anticancer activity of lavender (Lavandulaangustifolia Mill.) essential oil through induction of both apoptosis and necrosis. Ann. Phytomedicine An Int. J. 2019, 7, 38-45. [CrossRef]

28. Westhoff, M.A.; Marschall, N.; Debatin, K.-M. Apoptosis in Cancer Pathogenesis and Anti-cancer Therapy; Gregory, C.D., Ed.; Advances in Experimental Medicine and Biology; Springer: Cham, Switzerland, 2016; Volume 930, ISBN 978-3-319-39404-6.

29. Söderlund, K.; Pérez-Tenorio, G.; Stål, O. Activation of the phosphatidylinositol 3-kinase/Akt pathway prevents radiation-induced apoptosis in breast cancer cells. Int. J. Oncol. 2005, 26, 25-32. [CrossRef]

30. Atale, N.; Gupta, S.; Yadav, U.C.S.; Rani, V. Cell-death assessment by fluorescent and nonfluorescent cytosolic and nuclear staining techniques. J. Microsc. 2014, 255, 7-19. [CrossRef]

31. Hengartner, M.O. The biochemistry of apoptosis. Nature 2000, 407, 770-776. [CrossRef]

32. Stennicke, H.R.; Salvesen, G.S. Caspases-Controlling intracellular signals by protease zymogen activation. Biochim. Biophys. Acta Protein Struct. Mol. Enzymol. 2000, 1477, 299-306. [CrossRef]

33. McComb, S.; Chan, P.K.; Guinot, A.; Hartmannsdottir, H.; Jenni, S.; Dobay, M.P.; Bourquin, J.P.; Bornhauser, B.C. Efficient apoptosis requires feedback amplification of upstream apoptotic signals by effector caspase-3 or -7 . Sci. Adv. 2019, 5, 1-12. [CrossRef] [PubMed]

34. Koh, W.; Jeong, S.J.; Lee, H.J.; Ryu, H.G.; Lee, E.O.; Ahn, K.S.; Bae, H.; Kim, S.H. Melatonin promotes puromycin-induced apoptosis with activation of caspase-3 and $5^{\prime}$-adenosine monophosphate-activated kinase-alpha in human leukemia HL-60 cells. J. Pineal Res. 2011, 50, 367-373. [CrossRef] [PubMed]

35. Prashar, A.; Locke, I.C.; Evans, C.S. Cytotoxicity of lavender oil and its major components to human skin cells. Cell Prolif. 2004, 37, 221-229. [CrossRef]

36. Wu, C.-S.; Chen, Y.-J.; Chen, J.J.W.; Shieh, J.-J.; Huang, C.-H.; Lin, P.-S.; Chang, G.-C.; Chang, J.-T.; Lin, C.-C. Terpinen-4-ol Induces Apoptosis in Human Nonsmall Cell Lung Cancer In Vitro and In Vivo. Evidence-Based Complement. Altern. Med. 2012, 2012,1-13. [CrossRef] [PubMed]

37. Itani, W.S.; El-Banna, S.H.; Hassan, S.B.; Larsson, R.L.; Bazarbachi, A.; Gali-Muhtasib, H.U. Anti colon cancer components from lebanese sage (Salvia libanotica) essential oil: Mechanistic basis. Cancer Biol. Ther. 2008, 7, 1765-1773. [CrossRef] [PubMed]

38. Rodenak-Kladniew, B.; Castro, A.; Stärkel, P.; De Saeger, C.; García de Bravo, M.; Crespo, R. Linalool induces cell cycle arrest and apoptosis in HepG2 cells through oxidative stress generation and modulation of Ras/MAPK and Akt/mTOR pathways. Life Sci. 2018, 199, 48-59. [CrossRef] [PubMed]

39. Chang, M.Y.; Shieh, D.E.; Chen, C.C.; Yeh, C.S.; Dong, H.P. Linalool induces cell cycle arrest and apoptosis in leukemia cells and cervical cancer cells through CDKIs. Int. J. Mol. Sci. 2015, 16, 28169-28179. [CrossRef]

40. Murata, S.; Shiragami, R.; Kosugi, C.; Tezuka, T.; Yamazaki, M.; Hirano, A.; Yoshimura, Y.; Suzuki, M.; Shuto, K.; Ohkohchi, N.; et al. Antitumor effect of 1, 8-cineole against colon cancer. Oncol. Rep. 2013, 30, 2647-2652. [CrossRef]

41. Cha, J.D.; Kim, Y.H.; Kim, J.Y. Essential oil and 1,8-cineole from Artemisia lavandulaefolia induces apoptosis in KB Cells via mitochondrial stress and caspase activation. Food Sci. Biotechnol. 2010, 19, 185-191. [CrossRef]

42. Garzoli, S.; Masci, V.L.; Ovidi, E.; Turchetti, G.; Zago, D.; Tiezzi, A. Chemical investigation of a biologically active Schinus molle L. leaf extract. J. Anal. Methods Chem. 2019, 2019, 8391263. [CrossRef]

43. Karnovsky, M.J. A formaldehyde-glutaraldehyde fixative of high osmolality for use in electron microscopy. J. Cell Biol. 1965, 27, 137-138.

44. Bradford, M.M. A rapid and sensitive method for the quantitation of microgram quantities of protein utilizing the principle of protein-dye binding. Anal. Biochem. 1976, 72, 248-254. [CrossRef] 
45. Donoso-Fierro, C.; Tiezzi, A.; Ovidi, E.; Ceccarelli, D.; Triggiani, D.; Mastrogiovanni, F.; Taddei, A.R.; Pérez, C.; Becerra, J.; Silva, M.; et al. Antiproliferative activity of yatein isolated from Austrocedrus chilensis against murine myeloma cells: Cytological studies and chemical investigations. Pharm. Biol. 2015, 53, 378-385. [CrossRef] [PubMed]

Sample Availability: Samples of the compounds are available on request to the authors.

(C) 2020 by the authors. Licensee MDPI, Basel, Switzerland. This article is an open access article distributed under the terms and conditions of the Creative Commons Attribution (CC BY) license (http://creativecommons.org/licenses/by/4.0/). 